Características ecológicas poblacionales de presuntos morfotipos de Tursiops truncatus en

la región transicional del Océano Pacífico Mexicano

\title{
Population ecological traits of Tursiops truncatus putative morphotypes in the transitional region of the Mexican Pacific Ocean
}

\author{
Lorena Viloria-Gómora and Luis Medrano-González*
}

\begin{abstract}
Departamento de Biología Evolutiva, Facultad de Ciencias, Universidad Nacional Autónoma de México. Av. Universidad 3000, Ciudad Universitaria, Coyoacán 04510, Ciudad de México, Distrito Federal, México. E-mail: Iviloria@uabcs.mx (LVG), medranol@ ciencias.unam.mx (LMG).

* Corresponding author
\end{abstract}

Introduction: The bottlenose dolphin (Tursiops truncatus) exhibits high morphological and ecological variation not yet resolved for intraspecific systematics and population identity. Different non-well defined morphotypes of this species are often sympatric in the transitional realm between the East Tropical Pacific, the Gulf of California and the East North Pacific. In order to gain insights about the relationship between morphological variation and population identity of bottlenose dolphins in this transitional region, we surveyed the Bahía de Banderas and its surroundings making a heuristic identification of putative morphotypes from size and coloration classes and examined the correspondence of the determined forms with ecological traits indicative of population identity.

Methods: We navigated a transect-set of 20,641 km between years 2003 and 2005 covering an area of ca. 2500 $\mathrm{km}^{2}$ in which we recorded 170 sightings and achieved 302 photographic identifications of 207 bottlenose dolphins. We examined and classified the variation of 18 ecological traits that include spatial and seasonal distribution of abundance, seasonal patterns of pod size and calving as well as dispersion parameters obtained from markrecapture data.

Results: We determined five putative morphotypes of which the small light-gray (GCP), the large light-gray (GCG) and the large dark (GOG) occurred regularly in the region. These morphotypes exhibited distinctive, though overlapped, geographic and seasonal distributions as well as different, though related, patterns of pod size, calving and dispersion. A classification analysis indicated an equidistant separation between the three forms being GCG intermediate between GCP and GOG.

Discussion: Our results suggest a model of a metapopulation with partially differentiated units determined by the narrow bounds between pelagic and coastal environments. A local conservation policy focused on bottlenose dolphins is needed for the apparently resident GCP form and its environment as well as for phylopatric animals of other forms and population affinities that may extend conservation benefits beyond Bahía de Banderas.

Key words: Calving; dispersion; mark-recapture method; metapopulation; pod size; spatial distribution; seasonal distribution; transects method. 


\section{Introduction}

Several small cetaceans exhibit considerable morphological and ecological variation along their geographic distributions mostly in relation with feeding adaptations (Perrin 1984) and this has often resulted in the distinction of subspecies or even species as it happened for the spotted dolphin (Stenella attenuata; Schnell et al. 1986), the common dolphins (Delphinus spp; Rosel et al. 1994) and even the Hector's dolphin (Cephalorhynchus hectori) which is endemic to the coasts of New Zealand (Baker et al. 2002). The genus Tursiops has a complicated and not yet resolved taxonomy for which several nominal species, subspecies and morphological types have been described (Hershkovitz 1966; Rice 1998). Currently, at least two species are recognized, Tursiops aduncus, which inhabits the Indian Ocean and the western Pacific Ocean and Tursiops truncatus, the bottlenose dolphin, in tropical and temperate waters world-wide. In particular, T. truncatus exhibits a great morphological variation that makes difficult to determine (sub) species identity (Gao et al. 1995; Rice 1998; Wang et al. 1999, 2000). Coastal and pelagic ecotypes have been generally recognized in different ocean basins but genetic, morphological and ecological characteristics of these forms vary among regions (Walker 1981; Duffield et al. 1983; Perrin 1984; Hersh and Duffield 1990; Dowling and Brown, 1993; Curry and Smith 1997; Hoelzel et al. 1998; Kingston and Rosel, 2004; Natoli et al. 2004; Segura et al. 2006; Perrin et al. 2011; Caballero et al. 2012; Lowther-Thieleking et al. 2015). Therefore, a solution to taxonomical and population identity problems for Tursiops truncatus is in need of supported explanations for morphological variation and also of information on the ecology of local populations.

A coastal and an oceanic form of the bottlenose dolphin in the eastern North Pacific have been recognized but so far, genetic and morphometric variation has been associated with such organismal distinction only in California waters in relation with different feeding (Walker 1981; Curry and Smith 1997; Natoli et al. 2004; Perrin et al. 2011; Lowther-Thieleking et al. 2015). A slight coastal-offshore differentiation has been observed also for bottlenose dolphins in the Gulf of California on the basis of genetic, morphological and stable-isotope variation (Vidal Hernández 1993; Segura et al. 2006). Bottlenose dolphins from the Gulf of California appear more closely related with the California offshore form (Lowther-Thieleking et al. 2015) and coastal forms from both regions exhibit lower genetic diversity when compared with their respective offshore forms. All this suggests that coastal forms are local differentiations from one large open oceanic population (Perrin et al. 2011; Segura et al. 2006; Lowther-Thieleking et al. 2015). In the transitional region south of Baja California, morphotypes are not well defined and different forms often occur in sympatry, probably occupying different niches (Urbán Ramírez 1983; Vidal Hernández 1993). Such a situation occurs specifically at Bahía de Banderas which is a biologically-rich and conservation-prioritary region in the oceanographic transition between the East Tropical Pacific, the Gulf of California and the East North Pacific (CONABIO-CONANP-TNCPRONATURA-FCF, UANL 2007). Research on bottlenose dolphins in Bahía de Banderas indicate the occurrence of a local population unit or herd (Ruiz Boijseauneau 1995; Rodríguez Vázquez et al. 2003), but data also exhibit traits of a large, open and socially-dynamical population (Mejía Olguín 2004). A preliminary analysis of mitochondrial (mt) DNA variation, indicates bottlenose dolphins from Bahía de Banderas as being part of a large open population and at the same time being differentiated with dolphins from other regions in the Gulf of California that show lower mtDNA diversity (Cerrillo-Espinosa and Flores-Ramírez 2012). In an analysis of dorsal fin morphometrics, bottlenose dolphins from Bahía de Banderas appear similar to dolphins from the Gulf of California where dolphins' dorsal fin exhibits high variation and local differentiation in contrast with dolphins from other regions in the Pacific coast of Baja California and the Gulf of México (Morteo Ortiz 2004). 
In this work we relate the morphological identity of bottlenose dolphins from Bahía de Banderas, as determined by apparent coloration and size, with ecological traits of population identity such as geographic and seasonal distribution, seasonal patterns of pod-size and calving as well as dispersion parameters given by the time-interval and distance among recaptures of photo-identified individuals. We look for insights to relate the species' morphological variation with population structure in this region that may provide elements for a policy addressed to its local conservation. Because morphotypes are not well defined in the transitional region of the Mexican Pacific Ocean, we had to depart from a heuristic identification of such types. Whether these types indeed exist and constitute different population entities must be observed on the consistencies among morphological and ecological data. As based on the observation of freeranging animals, we had no other elements to register than size and coloration and we had no instrumental devices to register such characters other than close observation and our boat. This investigation was undertaken after several years (1986-2002) of observation by senior author who noticed the more detailed characters that may be registered with confidence under appropriate observation conditions.

\section{Methods}

Sea work. Between January 2003 and April 2005, we surveyed an area of ca. 2,500 km² in Bahía de Banderas and surrounding waters in the Mexican Pacific Ocean using outboard boats during light hours. This area was calculated from a transect-set of 20,641 km in total (Figure 1). The visited area was partitioned in six zones with different topographies and interactions with the neighboring lands defined mostly by the outflow of several rivers in the inner part of the bay and the environmental particularities around Marietas Islands (Figure 1). Seasons were classified as dry (January-June) and rainy (July-December) on the basis of climate data (e.g. Salinas Zacarías and Bourillón Moreno 1988) as well as on our own records of sea surface temperature (Figure 2). Bottlenose dolphins were observed as much as possible until a coloration class (light gray, dark gray or brownish) and a length-class (large or small) were identified. The comparison of the body size classes with the observing boat, allowed estimate that class partition is in the range of length $2.5-3.0 \mathrm{~m}$. We also registered the occurrence of a light coloration in the peduncle dorsum that defines a trait that we call "Socorro" and that we have observed in bottlenose dolphins from Revillagigedo Islands and Baja California (Figure 3). Size and color classes were recorded only when they were confidently determined after different light orientations of well-shown animals, near observation and consensus between at least three different observers to minimize subjectivity in data registration. Two sightings exhibited mixed light- and dark-colored animals. For these cases, we registered the light coloration that was the most abundant in these cases. Color and size were assigned for the entire pods only if well-grown animals were observed as judged from body-build, observable behavior (e.g. fights), scaring and presence of calves. From the 170 bottlenose dolphin sightings archieved, we were able to identify size and color classes only for entire 75 sightings as well as for 1,133 individuals out of 1,932 individuals in total.

Identification and ecological traits of putative morphotypes. Morphotypes were defined by the positive correlation of color and size classes determined with the $x^{2}$ test for individuals. Relative abundance per morphotype, zone and season was defined as the number of individuals per surveyed distance between sightings. The navigated distance, partitioned by zones and seasons was calculated using the program SECTONAV developed by L. Medrano-González. Calculations considered the Earth's curvature and elliptical form. A pod was defined as all animals within a distance of ca. $500 \mathrm{~m}$ from the observing boat (Defran and Weller 1999). Accurate pod size determination was only possible in a few cases with up to 20 individuals. For very scattered groups, pod size was approached with several trials of three times the number of individuals seen 
at once around the observing boat. Pod size was registered always as a consensus between at least three observers. Pod size was tested by the independent Student's t-test between seasons within morphotypes as well as between morphotypes within seasons. Since the counting of calves is even less accurate than pod size, calving patterns were examined as the fraction of sightings including at least one calf partitioned by morphotypes and seasons. The calving rate was tested among seasons within morphotypes as well as between morphotypes within seasons with the $c^{2}$ test on the number of sightings with and without calves.
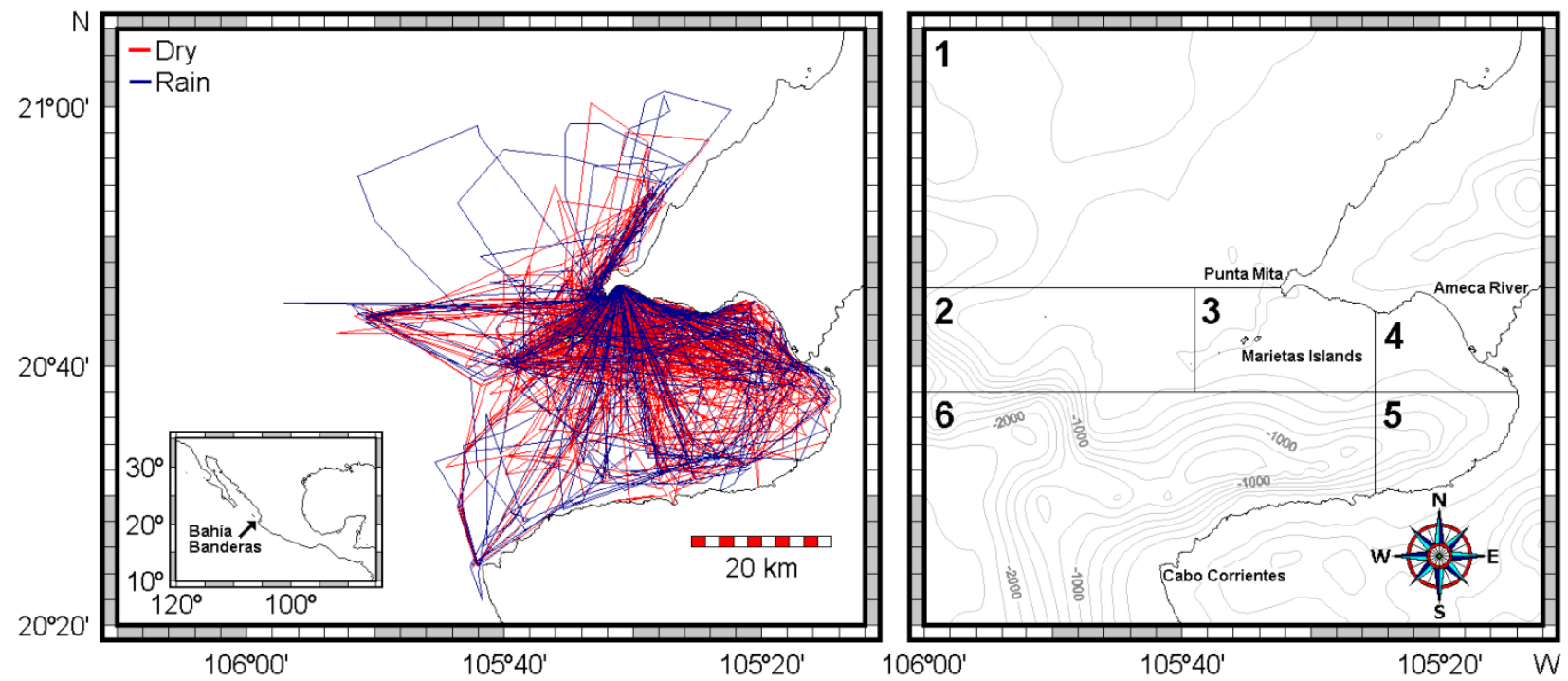

Figure 1. Left: Total survey effort for bottlenose dolphins in Bahía de Banderas and surrounding waters between January 2003 and April 2005. Navigation on the dry season is shown in red and during the rainy season in blue. Right: Partition of the visited area in six zones based on the indicated bathymetry and influence from neighboring lands. Isobaths are shown in meters.

Photographic marking. We identified individual dolphins by getting film-photographs (ASA 400) of their dorsal fins that were later digitalized to TIF format. Only photographs with resolution, focus, illumination and orientation appropriate to easily distinguish individuals were examined. We made a total of 302 identifications of 207 individuals with assigned classes of color and size determined during observation as described above. Color and size classes were independently assigned to each identification, this is, without knowledge of previous morphological assignments for recaptured animals. This procedure allowed evaluation of error in morphotype assignment when attained. We compared our photo-identification catalogue with the one developed by Ruiz Boijseauneau (1995). We used our mark-recapture data here to examine the morphotypes' dispersion as related with the distribution of animals. We left apart an extensive analysis of absolute abundance (Viloria Gómora 2007).

Dispersion patterns. For all the $302-207=95$ recaptures of bottlenose dolphins, time intervals and distance between consecutive records were obtained. The dispersion velocity was then calculated as the ratio of distance per time interval between captures. Since the data of dispersion distance are bounded at least to the surveyed area, dispersion velocity decays along time yielding and apparent power function which was fitted with a linear regression in the log-log plot. Dispersion was then described with the maximum distance found between recaptures and the parameters $V_{1}$ and $k$ of the following ad hoc function:

$$
V_{t}=V_{1} t^{k}
$$


Where $V_{t}$ is the dispersion velocity at time interval $t, V_{1}$ is the distance travelled by dolphins in one day and $k<0$ is the decaying rate of dispersion velocity in time. Mind that dispersal events beyond the surveyed area cannot be detected. To hint how different the dispersion patterns of bottlenose dolphin morphotypes are, these were compared with the dispersion pattern of a different species, the rough-toothed dolphin (Steno bredanensis), that was obtained with the same search effort and previous data from our research group compiled by Pompa Mansilla (2007).

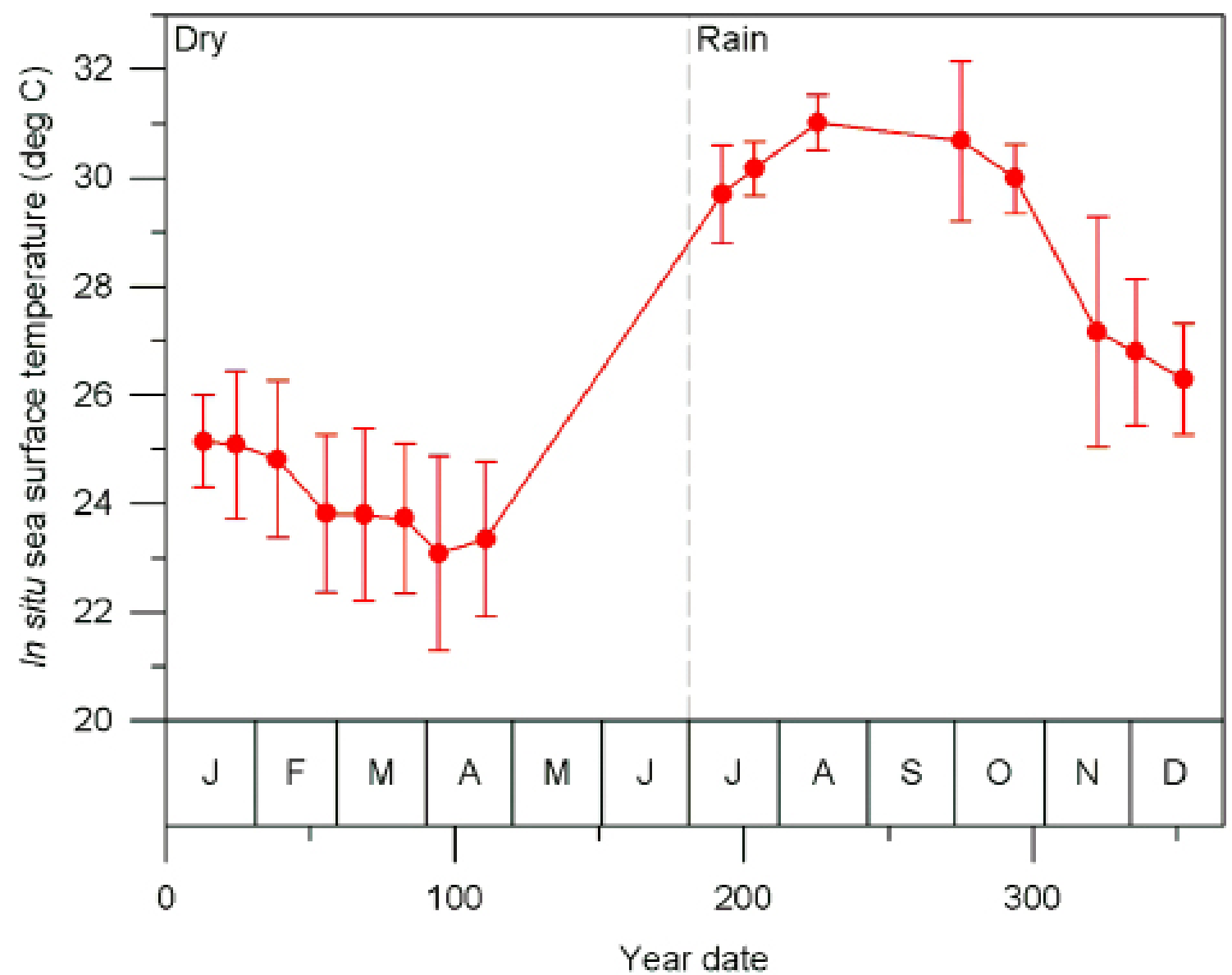

Figure 2. Mean profile of sea surface temperature along the year date for 5291 data at the Bahía de Banderas region recorded between years 1982 and 2015. Error bars indicate standard deviation. The dashed line show the partition of dry (January-June) and rainy (July-December) seasons.

Ecological classification of morphotypes: For the three putative morphotypes of bottlenose dolphins, we compiled their relative abundance in each zone and season ( 9 characters as bottlenose dolphins were not observed in all zone and season combinations), the seasonal average of pod size and its standard deviation ( 4 characters), the seasonal occurrence of calves ( 2 characters) as well as the parameters for dispersion ( 3 characters). The population ecological traits analyzed are differentially influenced by the environment and change in different time scales. However, the statistical distributions of these traits are theoretically expected to be the same or similar for a population entity (deme) during an observation period with given conditions. For example, pod size may change in a few minutes but its statistical distribution is expected to be repeated after several observations if the determinants for the animals grouping have not changed. Such changes in animals grouping anyway are alternative hypotheses that leave trait variation as indication of population identity. The population ecological traits used to describe heuristic morphotypes were abbreviated as follows: Abundances were indicated with character A followed by the zone number and a season character ( $D$ for the dry season or $\mathrm{R}$ for the rain season); pod size was indicated with character $\mathrm{P}$ followed by an 
A for the average and a D for the standard deviation and finally by the season character; calving was indicated with character $C$ followed by the season character. Dispersion parameters were indicated as Dmx for the maximum distance between consecutive recaptures, $\mathrm{V} 1$ for the distance traveled in one day and $\mathrm{k}$ for the decaying rate of dispersion velocity along time. Notice that the ecological traits employed are assignable to the data grouped by putative morphotype and not to the individual data within groups. This restrains the contrast of variation within and between morphotypes. The total 18 ecological traits (Table 1 ) were normalized by the variation among the three main morphotypes as follows:

$$
X_{i}^{n}=\frac{X_{i}-A_{i}}{D_{i}}
$$

where $X_{i}^{n}$ is the normalized value of trait $i, X_{i}$ is the original trait value for each morphotype, $A_{i}$ is the average of trait $i$ among morphotypes and $D_{i}$ is its corresponding standard deviation. Normalized traits data were entered into an analysis of principal components performed with program STATISTICA 7. The Euclidean distance among the three main morphotypes was also calculated as the standard deviation of the 18 ecological traits as follows:

$$
E_{Z}=\sqrt{\frac{\sum_{i=1}^{k}\left(X_{I}^{n}-X_{Z}^{n}\right)^{2}}{k-1}}
$$

where $E_{Y Z}$ is the Euclidean distance among morphotypes $Y$ and $Z, X_{i Y}^{n}$ and $X_{i Z}^{n}$ are the normalized values of trait $i$ in morphotypes $Y$ and $Z$ respectively and $k$ is the total number of traits. Canonical correlations were estimated between the 18 normalized ecological traits. The 18 traits were also entered into a paired Student's t-test.

Table 1. Definition of the 18 ecological traits used to determine the population similarity among the three putative morphotypes of bottlenose dolphins at Bahía de Banderas.

\begin{tabular}{ll} 
Abbreviation & \multicolumn{1}{c}{ Trait } \\
\hline A1D & Relative abundance at region 1 during the dry season. \\
A1R & Relative abundance at region 1 during the rainy season. \\
A2D & Relative abundance at region 2 during the dry season. \\
A3D & Relative abundance at region 3 during the dry season. \\
A3R & Relative abundance at region 3 during the rainy season. \\
A4D & Relative abundance at region 4 during the dry season. \\
A4R & Relative abundance at region 4 during the rainy season. \\
A5D & Relative abundance at region 5 during the dry season. \\
A5R & Relative abundance at region 5 during the rainy season. \\
PAD & Pod size average during the dry season. \\
PDD & Pod size standard deviation during the dry season. \\
PAR & Pod size average during the rainy season. \\
PDR & Pod size standard deviation during the rainy season. \\
CD & Fraction of sightings having at least one calf during the dry season. \\
CR & Fraction of sightings having at least one calf during the rainy season. \\
V1 & Distance traveled in one day. \\
$\mathrm{K}$ & Decaying rate of dispersion velocity along time. \\
Dmx & Maximum distance between consecutive recaptures. \\
\hline
\end{tabular}



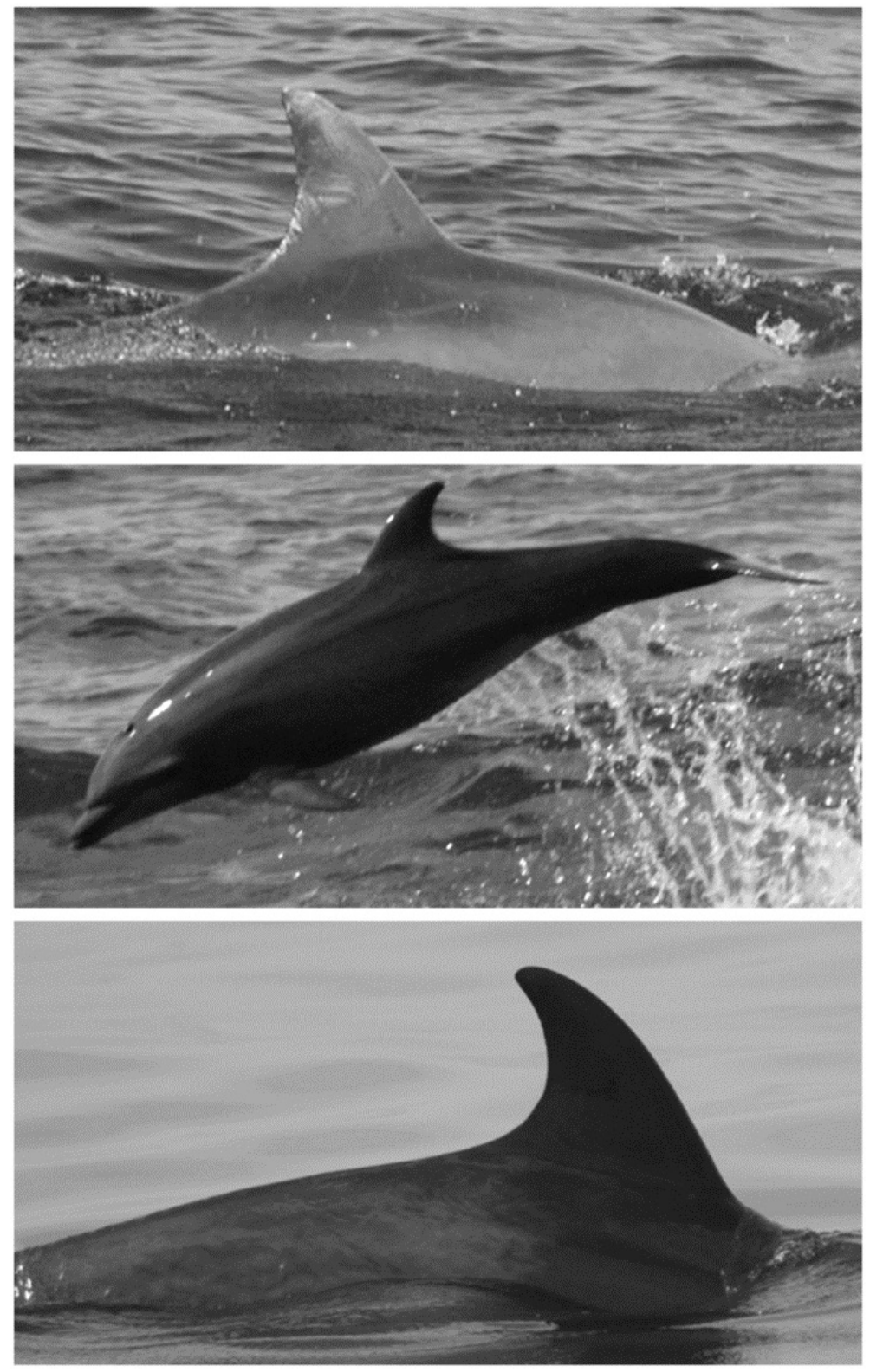

Figure 3. Tone classes of bottlenose dolphins in Bahía de Banderas. Upper: Light gray class (by L. Viloria-Gómora). Middle: Dark gray class (by H. Rosales-Nanduca). Lower: Individual exhibiting the lighter peduncle dorsum that we call Socorro trait (by L. ViloriaGómora). Brightness was slightly adjusted among the three pictures to show the water background with the same tone without making any modification in contrast.

\section{Results}

Heuristic identification of morphotypes. From the 170 sightings of bottlenose dolphins achieved, only in 75 size and color classes were identified for the entire pod to yield an assignment efficiency of $(75 / 170)=0.44$ for sightings. Efficiency of form assignment for observed individuals was $(1,133 / 1,932)$ $=0.59$. We identified the putative forms small light-gray (GCP, 18 sightings), large light-gray (GCG, 38 sightings), large dark (GOG, 12 sightings), small brownish (CaP, 3 sightings) and large Socorro (SoG, 4 sightings). For the combination of size and color classes among 1,133 observed individuals (Table 2 ), the $\chi^{2}$ correlation was not significant for GCG given the occurrence of the also large GCP and GOG forms but the high amount of GCG individuals and sightings indicates that they must be considered a form (Table 2). The small brownish form was identified only in 11 individuals and one individual identified first as CaP was assigned to the GCP form in a recapture. Therefore, the CaP form may be 
part of the GCP form or a marginal form in the region. The Socorro form may be related with the dark form given their association with large size or it may be also marginal in the region given its low occurrence (Table 2). Resolving if true morphotypes are defined by size or color classes only, must thus come from finding high ecological similarity among the three main apparent forms GCP, GCG and GOG. With exception of the individual identified as CaP in its first capture and recaptured as GCP described above, all individuals with independent assignment of size and color in mark and recapture events (46) exhibited concordant morphotype identifications. This yields a global error in form assignment of $(1 /(46+1))=0.02$ when the assignment was achieved.

Table 2. Number of bottlenose dolphins in Bahía de Banderas with assigned classes of size and color. Numbers within parentheses indicate the $x^{2}$ value.

\begin{tabular}{lccc} 
& Large & Small & Total \\
\hline Light gray & $569(3.89)$ & $324(11.3)$ & $\mathbf{8 9 3 ( 1 5 . 2 )}$ \\
Dark gray & $193(17.1)$ & $0(49.5)$ & $\mathbf{1 9 3 ( 6 6 . 5 )}$ \\
Brownish & $0(8.12)$ & $11(23.7)$ & $\mathbf{1 1 ( 3 1 . 9 )}$ \\
Socorro & $36(2.12)$ & $0(6.15)$ & $\mathbf{3 6 ( 8 . 2 7 )}$ \\
Total & $\mathbf{7 9 8 ( 3 1 . 2 )}$ & $\mathbf{3 3 5 ( 9 0 . 6 )}$ & $\mathbf{1 1 3 3 ( 1 2 2 )}$ \\
\hline
\end{tabular}

$X^{2}=7.815, p=0.050 ; X^{2}=16.266, \underline{P}=0.001$ for three degrees of freedom.

Spatial and seasonal distribution. The general distribution of bottlenose dolphins that we found in Bahía de Banderas is almost the same described by Ruiz Boijseauneau (1995) and Mejía Olguín (2004). Relative abundance is higher in the northern shallow zone within the bay (zone 4) near the Ameca River followed by zones two and three in the shallow area out of the bay and in the bay's northern opening respectively (Table 3; Figure 4). Calves occurred close to the shore, especially in the inner northern zone four. General abundance is lower in the rain season and the distribution during this time of the year also expands towards open waters in the North and deeper waters in the South. This seasonal pattern is similar for bottlenose dolphins in general as well as for the individual morphotypes (Table 3; Figure 4). The GCG form exhibits the largest abundance among morphotypes (0.03 individuals $/ \mathrm{km}$ ) and it is more abundant in the external shallow zones two, three and one as well as in the internal zone four. The GCP form instead ( 0.01 individuals $/ \mathrm{km}$ ), is more abundant in the internal zone four, the external zones three and two and the internal and deep zone five. The GOG form ( 0.01 individuals $/ \mathrm{km}$ ) appears to have a disrupted distribution in the internal zone four and in the external zones two and one (Table 3; Figure 4).

Pod size and calving patterns: For all bottlenose dolphins and for the three putative morphotypes, pod size was larger in the dry season and was larger too when calves were present. General mean pod size in the dry season was $13.0 \pm 14.1$ with no calves and $20.3 \pm 12.8$ with calves $(P=0.114)$. For the rain season, mean pod size was $7.8 \pm 8.0$ with no calves and $8.2 \pm 6.0$ with calves $(P=0.742)$. Pod size was statistically different between the dry and the rain season for both, groups with and without calves $(P<0.017$; Table 4; Figure 5$)$. In the dry season the GOG form shows the largest mean pod size $(20.3 \pm 13.6)$ followed by the GCG form (18.0 \pm 15.1$)$ and the GCP form (12.1 \pm 10.9$)$. In the rain season, mean pod size is smaller, less variable and similar among morphotypes with 7.1 \pm 3.6 for GOG, $8.4 \pm 6.8$ for GCG and $8.3 \pm 5.4$ for GCP. Statistical significance of seasonal variation for pod change was observed for the putative forms GCG and GOG. No statistical significance was observed for pod size variation among morphotypes within seasons (Table 4; Figure 5).

Calving, defined as the fraction of sightings having at least one calf, is larger in the rain season for all bottlenose dolphins and for the morphotypes. The ratio between calving in the rain season and calving in the dry season was 1.63 for all dolphins, 1.75 for the GCP form, 3.75 for the GCG form 
and 3.00 for the GOG form (Table 5). Seasonality in calving is thus apparently more marked for GCG and GOG forms. GOG was also the form with higher calving values. No statistical significance was detected for calving rate variation among morphotypes or seasons. Pod size and calving patterns among morphotypes must be considered with caution as these data for the identified forms were scarce (Table 5).

Table 3. Navigation effort $(\mathrm{km})$ and relative abundance $(\mathrm{ab})$ of bottlenose dolphin putative morphotypes (GCP, GCG and GOG; individuals $/ \mathrm{km}$ ) on the six zones of Bahía de Banderas at Figure 1 during dry and rain seasons.

\begin{tabular}{lrrrrrrr} 
& Zone 1 & \multicolumn{1}{c}{ Zone $\mathbf{2}$} & \multicolumn{1}{l}{ Zone 3 } & Zone 4 & Zone 5 & Zone 6 & Total \\
\hline Effort on dry & $1,170.1$ & 767.4 & 7918.5 & $2,206.0$ & $1,661.7$ & 789.1 & $\mathbf{1 4 , 5 1 2 . 8}$ \\
Effort on rain & 839.5 & 471.4 & 2501.7 & 796.9 & 1132.7 & 385.9 & $\mathbf{6 , 1 2 8 . 1}$ \\
Effort total & $\mathbf{2 , 0 0 9 . 6}$ & $\mathbf{1 , 2 3 8 . 8}$ & $\mathbf{1 0 , 4 2 0 . 2}$ & $\mathbf{3 , 0 0 2 . 9}$ & $\mathbf{2 , 7 9 4 . 5}$ & $\mathbf{1 , 1 7 5 . 0}$ & $\mathbf{2 0 , 6 4 0 . 8}$ \\
& & & & & & & \\
GCP ab on dry & 0.000 & 0.004 & 0.012 & 0.032 & 0.000 & 0.000 & $\mathbf{0 . 0 1 2}$ \\
GCP ab on rain & 0.000 & 0.000 & 0.011 & 0.000 & 0.004 & 0.003 & $\mathbf{0 . 0 0 5}$ \\
GCG ab on dry & 0.017 & 0.065 & 0.025 & 0.122 & 0.003 & 0.000 & $\mathbf{0 . 0 3 7}$ \\
GCG ab on rain & 0.004 & 0.000 & 0.014 & 0.038 & 0.000 & 0.000 & $\mathbf{0 . 0 1 1}$ \\
GOG ab on dry & 0.017 & 0.026 & 0.012 & 0.023 & 0.000 & 0.000 & $\mathbf{0 . 0 1 3}$ \\
GOG ab on rain & 0.004 & 0.000 & 0.004 & 0.010 & 0.000 & 0.000 & $\mathbf{0 . 0 0 3}$ \\
Total ab on dry & 0.053 & 0.159 & 0.088 & 0.208 & 0.036 & 0.000 & $\mathbf{0 . 1 7 8}$ \\
Tota ab on rain & 0.051 & 0.078 & 0.057 & 0.248 & 0.032 & 0.047 & $\mathbf{0 . 1 4 3}$ \\
Total ab & $\mathbf{0 . 0 5 2}$ & $\mathbf{0 . 1 2 8}$ & $\mathbf{0 . 0 8 0}$ & $\mathbf{0 . 2 1 9}$ & $\mathbf{0 . 0 3 4}$ & $\mathbf{0 . 0 1 5}$ & $\mathbf{0 . 1 6 8}$ \\
\hline
\end{tabular}

Dispersion patterns. Comparison of our photographic catalog with the catalog by Ruiz Boijseauneau (1995) yielded two matches, one for a GOG individual with 5,502 days between captures and another for a GCP individual with 4,015 days between captures. For the GCG form and the rough-toothed dolphin, the longest recapture intervals in our data were 406 days and 1968 days respectively. The largest dispersion distance observed between consecutive recaptures ( $\mathrm{Dmx}$ ) in our data were 41 km for GCP, $47 \mathrm{~km}$ for GCG, $71 \mathrm{~km}$ for GOG and $56 \mathrm{~km}$ for the rough-toothed dolphin (Table 6). Dispersion of the bottlenose and rough-toothed dolphins appears as a negative power law for the velocity of dispersion along time since dispersion distance is bounded at least to the surveyed area. According to this model for dispersal (Table 6; Figure 6), the GCP form shows a higher travel distance in one day, a smaller maximum distance between captures and a higher rate of decaying dispersion-velocity along time. The latter implies that the GCP form could disperse over smaller areas faster than other putative bottlenose dolphin morphotypes and dolphin species. On the other hand, the dispersion parameters for the GOG form indicate that these dolphins disperse more slowly over larger areas as compared with the other dolphins. The dispersion parameters of the GCG form appear intermediate between GCP and GOG. The rough-toothed dolphin exhibits a dispersal pattern in which these animals seemingly travel long distances in short times covering a large area. However, our data suggest that rough-toothed dolphins do not disperse as fast as the bottlenose GCP putative form and neither cover an area as large as the bottlenose GOG putative form (Table 6; Figure 6). Standard errors of the regression parameter $V_{1}$ (distance travelled by dolphins in one day) do not overlap among putative morphotypes or the two dolphin species. For parameter $k$ (the decaying rate of dispersion velocity in time), standard errors exhibit a degree of overlapping among the rank-adjacent morphotypes or species (Table 6).

Ecological classification of morphotypes. We determined the relationship between the three putative morphotypes of bottlenose dolphins in terms of population ecology performing a classification analysis of principal components based on nine characters of spatial and seasonal 

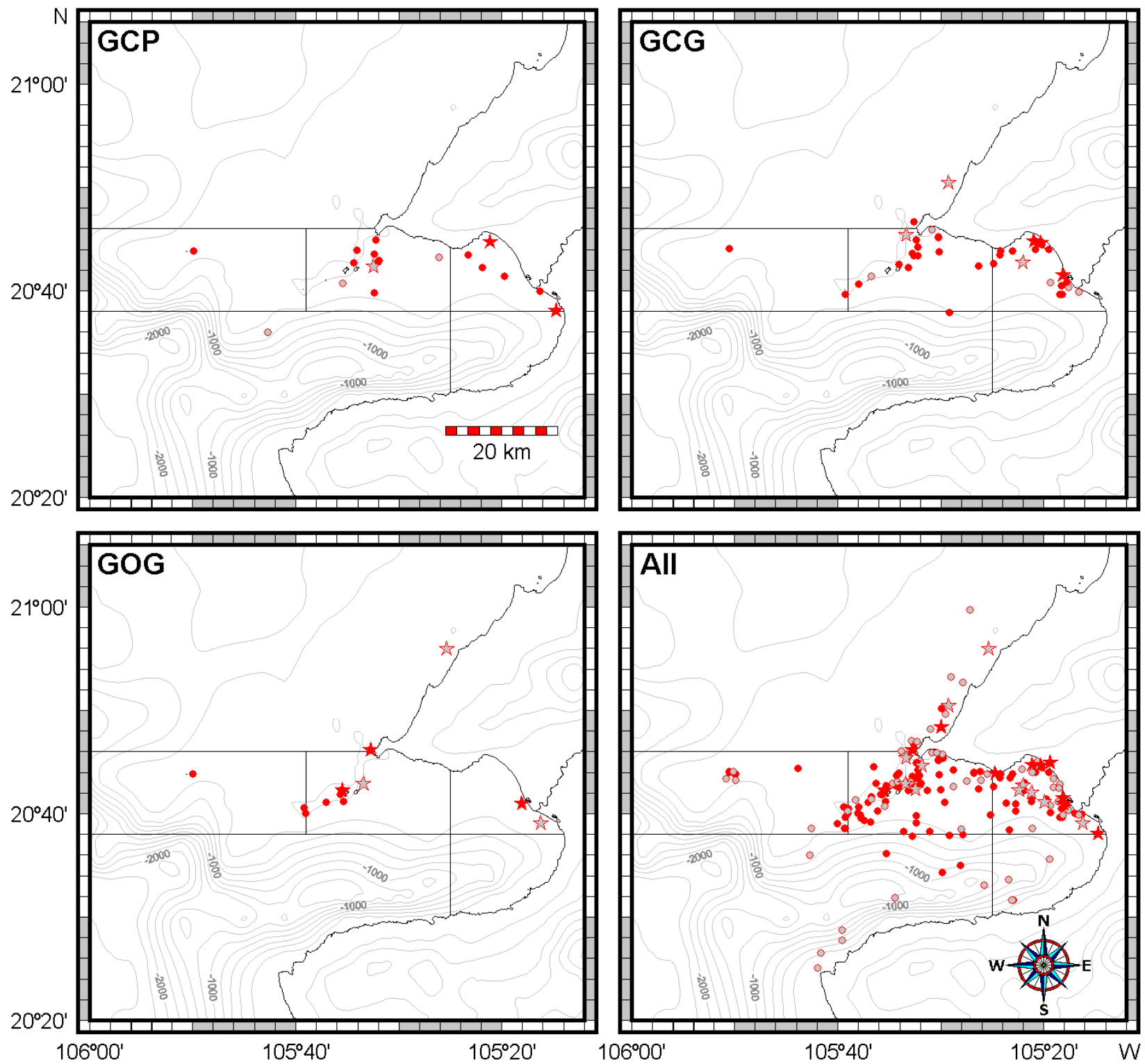

Figure 4. Records of all and the three putative morphotypes (GCP, GCG and GOG) of bottlenose dolphins in Bahía de Banderas. Circles depict sightings without calves and stars stand for pods having at least one calf. Dark symbols stand for the dry season and light symbols for the rainy season.

abundance, four characters on the seasonal variation of pod size, two characters on the seasonal occurrence of calves and three characters on the dispersion parameters obtained from markrecapture data. Since we examined variation among the three main morphotypes of bottlenose dolphins, the two first components accounted for the total variation. The first principal component contained $56.3 \%$ of the whole variation. The three morphotypes appeared equidistant around the center of the principal components plane indicating that they are equally distinctive. The 18 traits appeared in a circle around the center indicating that they are equally informative to define morphotypes (Figure 7). This analysis also shows associations between morphotypes and traits. Traits V1 and A5R distinguish the GCP form with minimum distance between traits and morphotype on the principal components plot of 2.61 in average and canonical correlation of 0.93; traits Dmx, $\mathrm{CR}$ and $\mathrm{CD}$ distinguish the GOG form with minimum distance between traits and morphotype on the principal components plot of 2.59 in average and mean canonical correlation of 0.96; traits A2D, A3D, A4D, A4R and A5D distinguish the GCG form with minimum distance between traits and morphotype on the principal components plot of 2.27 in average and mean canonical correlation 
of 0.96; traits PDR, PAR and A3R are associated with GCP and GCG, and traits A1R, A1D, PDD, PAD and $\mathrm{k}$ are associated with GCG and GOG (Figure 7). No traits were associated with the combination of GCP and GOG and this also is reflected in the fact that the Euclidean distance between GCP and GCG is the same than the distance between GCG and GOG (1.37) whereas the distance between GCP and GOG is slightly larger (1.50). This means that the GCG form is ecologically intermediate between GCP and GOG. When the normalized values of the 18 ecological traits were compared among the three putative morphotypes using the paired Student's t-test, only the comparison between GCP and GCG was statistically significant with type I error of $P=0.004$. (Figure 5).

Table 4. Pod size of bottlenose dolphin putative morphotypes (GCP, GCG and GOG) at Bahía de Banderas during dry and rain seasons

\begin{tabular}{|c|c|c|c|c|}
\hline & Mean pod size & Standard deviation & $n^{*}$ & $\begin{array}{c}\text { Probability for } \\
\text { comparison dry vs rain }\end{array}$ \\
\hline GCP on dry & 12.07 & 10.85 & 14 & \multirow{2}{*}{0.355} \\
\hline GCP on rain & 8.25 & 5.38 & 4 & \\
\hline GCG on dry & 18.00 & 15.07 & 30 & \multirow{2}{*}{0.014} \\
\hline GCG on rain & 8.38 & 6.78 & 8 & \\
\hline GOG on dry & 20.33 & 16.27 & 9 & \multirow{2}{*}{0.045} \\
\hline GOG on rain & 7.00 & 3.61 & 3 & \\
\hline Unassigned on dry & 10.27 & 13.01 & 49 & \multirow{2}{*}{0.206} \\
\hline Unassigend on rain & 7.45 & 8.22 & 47 & \\
\hline Total on dry & 13.68 & 14.05 & 102 & \multirow{2}{*}{0.168} \\
\hline Total on rain & 7.60 & 7.63 & 62 & \\
\hline
\end{tabular}

* Data for six sightings are missing.

\section{Discussion}

Genetic, morphological and ecological variation of bottlenose dolphins in the East Tropical Pacific does not correspond to the traditional descriptions of coastal and pelagic forms described in other regions that include waters off California (Walker 1981; Urbán Ramírez 1983; Perrin 1984; Vidal Hernández 1993; Curry and Smith 1997; Natoli et al. 2004; Perrin et al. 2011; Lowther-Thieleking et al. 2015). This uncertainty on variation and population identity is of concern as the intense interactions of bottlenose dolphins with human enterprises, especially fishing, tourism and urban development along the coasts (e. g. Arellano Peralta and Medrano González 2013), could pose severe threats for some local populations that might not be detected given the sympatric occurrence of other open and large populations of the same species.

Upon further validation of our results, for the Bahía de Banderas region, at the transitional realm of the Mexican Pacific Ocean, we recognized five forms of bottlenose dolphins of which the ones that we abbreviate CaP and SoG seem to be part of the GCP and GOG forms respectively, or might be even marginal in the region. Our results thus suggest the occurrence of three putative forms in the Bahía de Banderas region, abbreviated GCP, GCG and GOG, that appear morphologically and ecologically distinctive although they exhibit overlapped distributions and similar patterns of group size, calving and dispersion. The GOG form seems to inhabit more open waters and disperses on a larger area although slowly as compared with other forms. The GOG form also exhibits larger pod sizes and calving values. Most of these attributes suggest that the GOG form could be defined as pelagic. Contrastingly, the GCP form appears inhabiting more on the inner part of the bay including deep waters in the south and disperses fast in a smaller area as compared with other forms. The GCP form also shows the smaller pod sizes and lower calving values. Seasonal variation of pod size was 
statistically significant only for the apparently non-local forms GCG and GOG being this result due to both, larger sample sizes and larger seasonal differences. Moreover, calving of the GCP form is the less seasonal suggesting that these animals may be resident in the region. Therefore, the preliminary high calving values recorded for the GOG form suggest the occurrence of this oceanic form in the Bahía de Banderas region associated with calving whereas the more resident GCP form may be observed engaged in other activities. For other oceanic and coastal cetaceans such as the pygmy sperm whale (Kogia sima), the rough-toothed dolphin, the pantropical spotted dolphin, the spinner dolphin (Stenella longirostris) and the humpback whale (Megaptera novaeangliae), calving rates in the Bahía de Banderas region are also higher than the calving rates recorded in open waters of the Mexican Pacific Ocean (Medrano González et al. 2007).
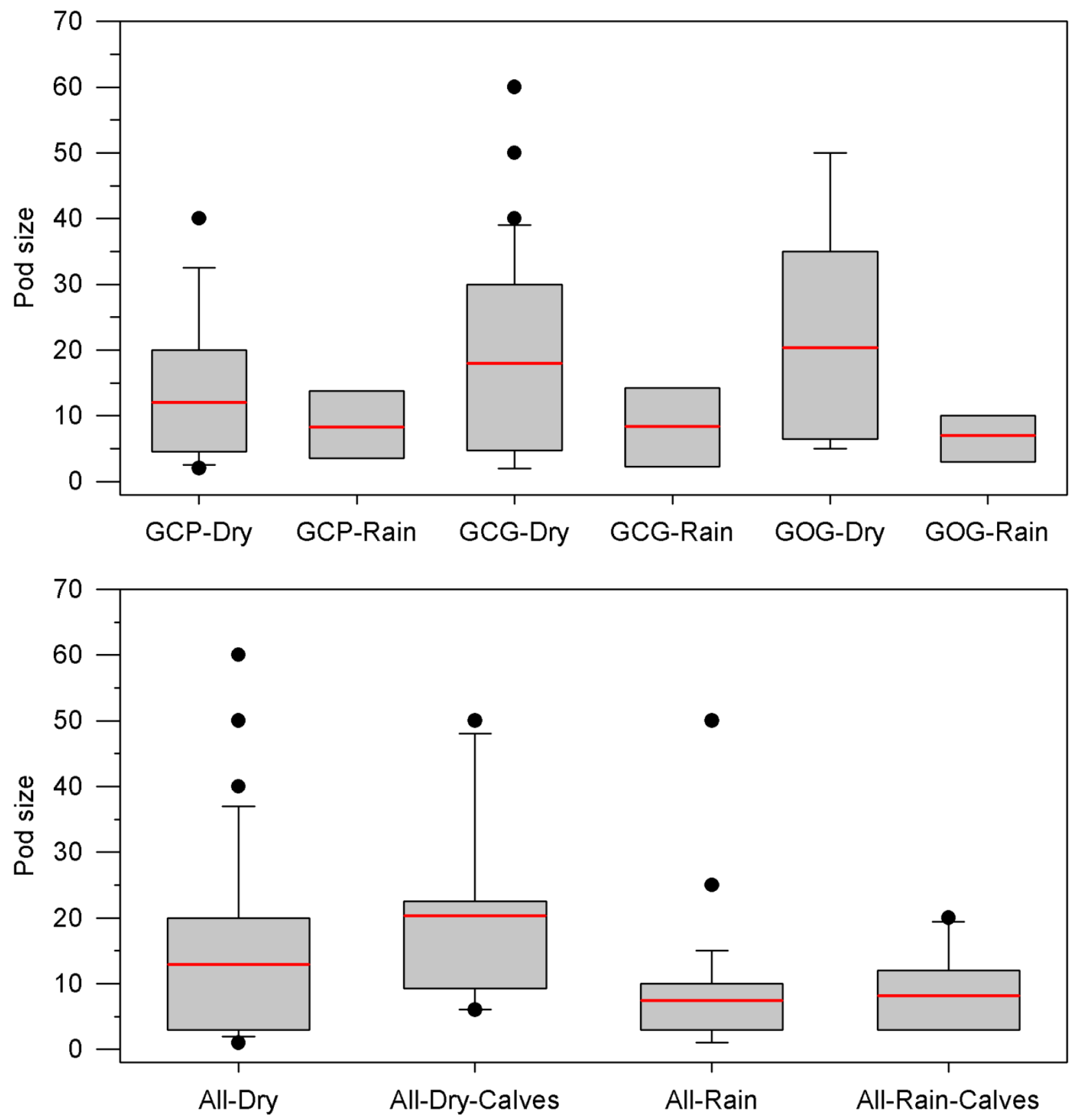

Figure 5. Box plots for pod size of bottlenose dolphins in Bahía de Banderas with indication of the mean values and outlying data. Upper: Partition of putative morphotypes (GCP, GCG and GOG) and seasons. Lower: Partition of calving and seasons for all sightings (Table 4). 
Table 5. Fraction of sightings with calves for bottlenose dolphin putative morphotypes (GCP, GCG and GOG) in Bahía de Banderas during dry and rain seasons.

\begin{tabular}{lcccccc} 
& Dry & Rain & Total & $\boldsymbol{n}$ dry & $\boldsymbol{n}$ rain & $\boldsymbol{n}$ total \\
\hline GCP & 0.143 & 0.250 & $\mathbf{0 . 1 6 7}$ & 14 & 4 & $\mathbf{1 8}$ \\
GCG & 0.100 & 0.375 & $\mathbf{0 . 1 5 8}$ & 30 & 8 & $\mathbf{3 8}$ \\
GOG & 0.333 & 1.000 & $\mathbf{0 . 5 0 0}$ & 9 & 3 & $\mathbf{1 2}$ \\
Unassigned & 0.038 & 0.080 & $\mathbf{0 . 0 5 9}$ & 52 & 50 & $\mathbf{1 0 2}$ \\
Total & $\mathbf{0 . 1 0 9}$ & $\mathbf{0 . 1 7 7}$ & $\mathbf{0 . 1 2 8}$ & $\mathbf{1 0 5}$ & $\mathbf{6 5}$ & $\mathbf{1 7 0}$ \\
\hline
\end{tabular}

Even though the GCG form is distinctive and is also the more abundant morphotype in the Bahía de Banderas region, it is in all morphological and ecological traits intermediate between the GOG and the GCP forms. In a related study of the dorsal fin morphology using 20 quantitative and four qualitative characters for the three bottlenose dolphin putative morphotypes, the rough-toothed dolphin and the pygmy sperm whale, Juárez Rodríguez (2008), found statistically-significant differences between species as well as overlapped and equidistant differences between the three bottlenose dolphin putative morphotypes being the difference between GCG and GOG the only comparison statistically significant. Hence, morphological and ecological variation of bottlenose dolphins in the region may be interpreted as the overlapped occurrence of one open pelagic form (GOG) that calves in the coast, one local and coastal form (GCP) and an abundant intermediate form (GCG). Therefore, bottlenose dolphins in the Bahía de Banderas region could be viewed as a particular case of the general pelagic-coastal differentiation of the species in which there is population continuity with ordered variation around the reduced and near-land boundaries between the pelagic and coastal environments of this region. A metapopulation of one large oceanic population with local coastal demes and with extended intermediates around the pelagic-neritic frontier appears as a first model for bottlenose dolphins in the transitional region of the Mexican Pacific Ocean. Such a model could help to explain the preliminary mtDNA data by Cerrillo-Espinosa and Flores-Ramírez (2012) indicating that bottlenose dolphins from Bahía de Banderas are part of a large open population and that at the same time, they are differentiated with dolphins from other regions in the Gulf of California that show lower mtDNA diversity. Our metapopulation model can thus be interpreted in terms of the Wright's shifting balance theory (1932) in which local adaptations and genetic differentiation occur in the coasts simultaneously with population expansions and gene flow from the boundaries between the coasts and the open ocean. Such a pattern of population fragmentation in the coasts occurring simultaneously with panmixia in the pelagic realm has been described in a large and detailed geographical scale for the spotted dolphin in the eastern tropical Pacific Ocean by examination of mitochondrial and microsatellite DNA variation (Escorza-Treviño et al. 2005). These concurrent processes of coastal isolation and oceanic gene flow also appear associated in general with postglacial population expansions in tropical cetaceans (Medrano González 2006).

Table 6. Regression parameters with standard error (SE) for the profile of dispersion velocity along time in bottlenose dolphin putative morphotypes (GCP, GCG and GOG) and the rough-toothed dolphin at Bahía de Banderas (Figure 6).

\begin{tabular}{lcccc} 
& $\boldsymbol{V}_{\mathbf{1}} \pm \mathbf{S E}(\mathbf{k m})$ & $\boldsymbol{k} \pm \mathbf{S E}$ & Adjusted $\boldsymbol{r}^{\mathbf{2}}$ & $\boldsymbol{D m x}(\mathbf{k m})$ \\
\hline GCP & $27.2 \pm 2.55$ & $-1.201 \pm 0.205$ & 0.630 & 40.8 \\
GCG & $8.00 \pm 1.34$ & $-0.946 \pm 0.080$ & 0.664 & 47.3 \\
GOG & $3.88 \pm 1.67$ & $-0.772 \pm 0.128$ & 0.595 & 71.0 \\
S. bredanensis & $12.9 \pm 1.50$ & $-0.908 \pm 0.070$ & 0.844 & 56.1 \\
\hline
\end{tabular}




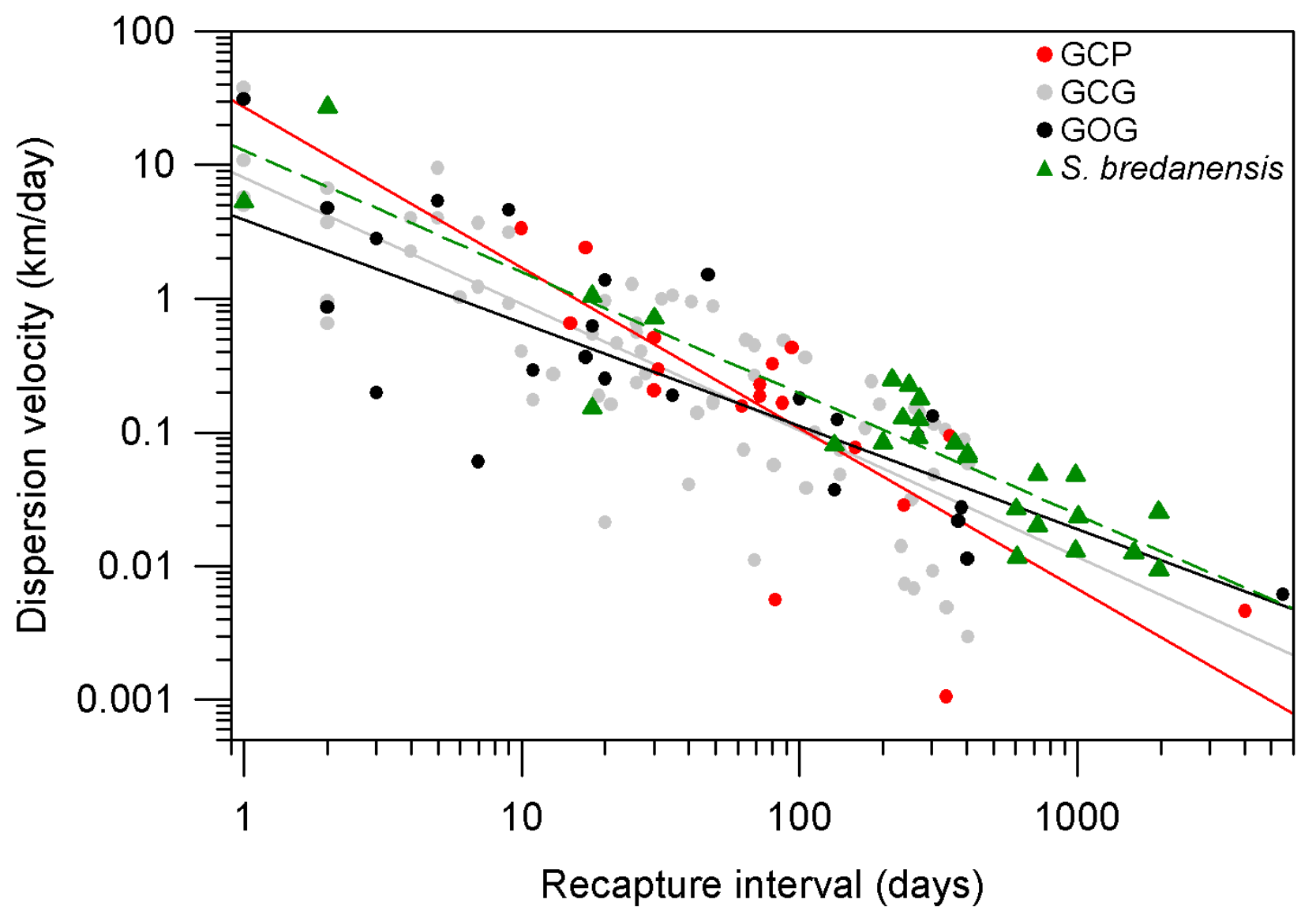

Figure 6. Dispersion patterns for bottlenose dolphin putative morphotypes (GCP, GCG and GOG) and the rough-toothed dolphin (S. bredanensis). The profile of dispersion velocity along time was fitted to a power function by means of a linear regression on a log-log plot (Table 6). Recapture data are indicated with gray circles for the GCG form, red circles for the GCP form, black circles for the GOG form and green triangles for the rough-toothed dolphin. The corresponding regression lines are also indicated being continuous for the bottlenose dolphin putative forms and dashed for the rough-toothed dolphin.

A noticeable indication of long-term site fidelity or residency for the GOG and GCP putative forms of bottlenose dolphins were evidenced by the photographic recapture of individuals in intervals of 15 and 11 years respectively; for rough-toothed dolphins, we recaptured individuals at least in a period of five years. These long-term records of individual occurrence indicate that the Bahía de Banderas region is an important habitat at least for bottlenose and rough-toothed dolphins. Bottlenose dolphins inhabit mostly the shallow northern part of the bay and are especially bound to the bay's inner zone. Calving of this species appeared particularly related to near-shore waters, especially within the bay and this was valid too for the three putative morphotypes. These areas however, are currently under an intense development of touristic activities, that include marine mammal watching, as well as to a ruthless urban development in the neighboring coasts that seriously pollute and deteriorate the marine environment (Arellano Peralta and Medrano González 2013). We increasingly observe interactions of bottlenose dolphins with rubbish items such as plastic bags and even toilet paper (e.g. Figure S1B in Arellano-Peralta and Medrano-González 2015). Pollution by rubbish, chemicals and pathogens is probably the greatest concern for small cetaceans in the Bahía de Banderas region (ArellanoPeralta and Medrano-González 2013, 2015) but risks may be higher for bottlenose dolphins and especially for the apparently resident GCP form, given their closer association with coasts under intense human influences. 
A set of local policies for marine conservation focused on bottlenose dolphins may benefit resident dolphins and the species related with them as well as phylopatric dolphins of other population affinities or species that may extend conservation benefits away from the region in terms of survival, reproduction and health. Conversely, negligence to develop such policies, especially regarding pathogens control, may extend the reach of some risks beyond the bay because dolphins can disperse far away the already high pathogenic load at the Bahía de Banderas coasts (Arellano Peralta and Medrano González 2013). Future research on marine mammals in the Bahía de Banderas region must develop a holistic and thus a multidisciplinary perspective of the ecosystem these animals inhabit as well as a comprehensive consideration to the social phenomena that are currently deteriorating the coastal and marine environments of this still biologically-rich region.

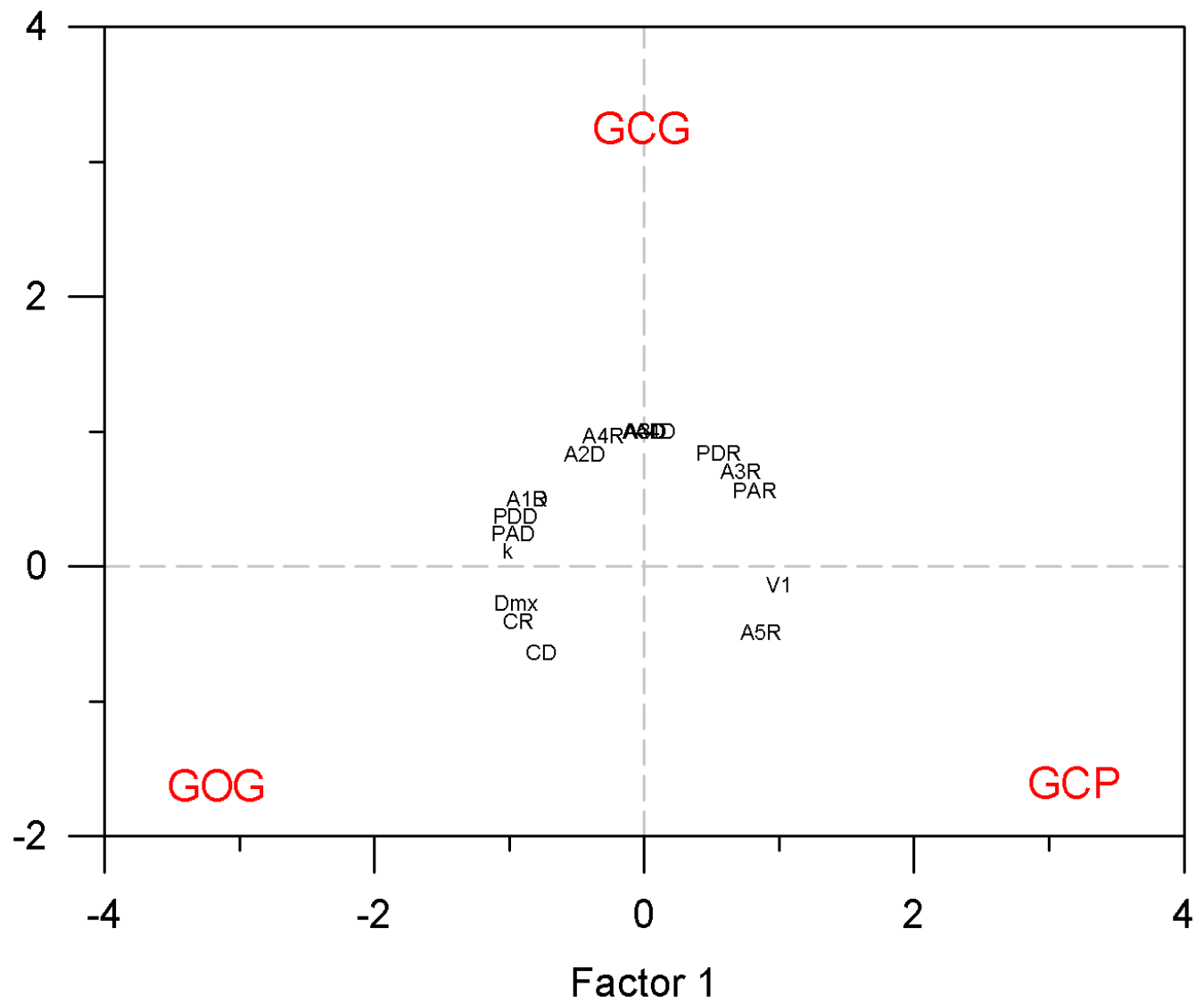

Figure 7. Principal components plot for the classification of the three main putative morphotypes of bottlenose dolphins (GCP, GCG and GOG) and the 18 population ecological traits described in Tables 3-6.

\section{Acknowledgments}

We are indebted to R. A. Juárez, C. A. López, S. Martínez, M. T. Núñez, S. Pompa, H. Rosales, E. C. Salazar, S. Smith, M. J. Villanueva as well as the family Niebla Olveras by their valuable efforts at sea and/or assistance in the laboratory. We also acknowledge M. J. Vázquez for her work on administration, legal issues and other facilities as well as A. Aguayo, J. Urbán, M. A. Salinas, L. F. Bourillón, C. Esquivel, I. Ruiz and A. Mejía for their seminal investigations on dolphins at Bahía de Banderas. We thank two anonymous reviewers whose positive and strong work greatly enriched this paper. Funding was provided by Consejo Nacional de Ciencia y Tecnología (projects 3725P-N9608 and 38605-V) and Instituto Nacional de Ecología. Legal authorization for research on marine mammals at Bahía de Banderas was given by Dirección General de Vida Silvestre, Secretaría del Medio Ambiente y Recursos Naturales. Authors declare no conflict of interest. 


\section{Resumen}

Introducción: La tonina (Tursiops truncatus) exhibe una alta variación morfológica y ecológica no resuelta en la sistemática intraespecífica e identidad poblacional. Diferentes morfotipos de esta especie no bien definidos suelen ser simpátricos en la transición entre el Pacífico Oriental tropical, el Golfo de California y el Pacífico Nororiental. Para conocer mejor la relación entre la variación morfológica y la identidad poblacional de las toninas en esta región de transición, inspeccionamos la Bahía de Banderas y sus alrededores haciendo una identificación heurística de presuntos morfotipos a partir de clases de tamaño y coloración y examinamos la correspondencia de las formas determinadas con rasgos ecológicos indicativos de identidad poblacional.

Métodos: Navegamos un conjunto total de transectos de 20,641 km entre los años 2003 y 2005 cubriendo un área de ca. $2500 \mathrm{~km}^{2}$ en la cual registramos 170 avistamientos y logramos 302 identificaciones fotográficas de 207 toninas. Examinamos y clasificamos la variación de 18 rasgos ecológicos que incluyen distribución espacial y estacional de abundancia, patrones estacionales del tamaño de grupo y crianza así como parámetros de dispersión obtenidos de datos de marcaje y recaptura.

Resultados: Determinamos cinco presuntos morfotipos de los cuales el gris claro pequeño (GCP), el gris claro grande (GCG) y el obscuro grande (GOG) fueron regulares en la región. Estos morfotipos mostraron distribuciones geográficas y estacionales diferentes pero traslapadas así como diferentes, aunque relacionados, patrones de tamaño de grupo, crianza y dispersión. Un análisis de clasificación indicó una separación equidistante entre las tres formas siendo GCG intermedia entre GCP y GOG.

Discusión: Nuestros resultados sugieren un modelo de una metapoblación con unidades parcialmente diferenciadas determinadas por los estrechos límites entre los ambientes costero y pelágico. Se requiere una política local de conservación orientada a las toninas que beneficiaría a la forma GCP que es aparentemente residente y a su ambiente así como a animales filopátricos de otras formas y afinidades poblacionales que podrían extender los beneficios de la conservación más allá de la Bahía de Banderas.

Palabras clave: Crianza; dispersión; distribución espacial y estacional; metapoblación; método de transectos, marcaje y recaptura; tamaño de grupo.

\section{References}

Arellano Peralta, V. A., and L. Medrano González. 2013. Mamíferos marinos en el golfo de California. Macroecología, impacto humano y su perspectiva hacia la conservación. Colección Posgrado 43. Universidad Nacional Autónoma de México. Ciudad de México, México.

Arellano-Peralta, V. A., and L. Medrano-González. 2015. Ecology, conservation and human history of marine mammals in the Gulf of California and Pacific coast of Baja California, Mexico. Ocean and Coastal Management 104:90-105.

Baker, A. N., A. N. H. Smith, And F. B. Pichler. 2002. Geographical variation in Hector's dolphin: Recognition of new subspecies of Cephalorhynchus hectori. Journal of the Royal Society of New Zealand 32:713-727.

Caballero, S., V. Islas-Villanueva, G. Tezanos-Pinto, S. Duchene, A. Delgado-Estrella, R. Sanchez-Okrucky, and A. A. Mignucci-Giannonı. 2012. Phylogeography, genetic diversity and population structure of common bottlenose dolphins in the Wider Caribbean inferred from analyses of mitochondrial DNA control region sequences and microsatellite loci: conservation and management implications. Animal Conservation 15:95-112.

Cerrillo-Espinosa, P., and S. Flores-Ramírez. 2012. Population identity and adaptive variation in bottlenose dolphins (Tursiops truncatus) at Bahía de Banderas, México. Abstract 34 in XXXIII Reunión internacional para el estudio de los mamíferos marinos. San Patricio Melaque, México.

CONABIO-CONANP-TNC-PRONATURA. 2007. Análisis de vacíos y omisiones en conservación de la biodiversidad marina de México: océanos costas e islas. Comisión Nacional para el Conocimiento y uso de la Biodiversidad, Comisión Nacional de Áreas Naturales Protegidas, The Nature ConservancyPrograma México, Pronatura A. C. Ciudad de México, México 
CurRY, B. E., AND J. Smith. 1997. Philogeographic structure of the bottlenose dolphin (Tursiops truncatus) stock identification and implications for management. Pp. 227-247 in Molecular genetics of marine mammals (Dizon, A. E. S. J. Chivers, and W. F. Perrin, eds.). Special publication 3, The Society for Marine Mammalogy. Lawrence, USA.

Defran, R. H., ANd B. W. Weller. 1999. Occurrence, distribution, site fidelity and school size of bottlenose dolphins (Tursiops truncatus) off San Diego, California. Marine Mammal Science 15:366-380.

Dowling, T. E., AND W. M. Brown. 1993. Population structure of the bottlenose dolphin (Tursiops truncatus) as determined by restriction endonuclease analysis of mitochondrial DNA. Marine Mammal Science 9:138-155.

Duffield, D. A., S. H. Ridgway, and L. H. Cornell. 1983. Hematology distinguishes coastal and offshore forms of dolphins (Tursiops). Canadian Journal of Zoology 61:930-933.

Escorza-Treviño, S., F. I. Archer, M. Rosales, A. Lang, and A. E. Dizon. 2005. Genetic differentiation and intraspecific structure of Eastern Tropical Pacific spotted dolphins, Stenella attenuata, revealed by DNA analyses. Conservation Genetics 6:587-600.

Gao, A., K. Zhou, And Y. WANG. 1995. Geographical variation in morphology of bottlenose dolphins (Tursiops sp.) in Chinese waters. Aquatic Mammals 21:121-135.

Hersh, S. L., And D. A. Duffield. 1990. Distinction between northwest Atlantic offshore and coastal bottlenose dolphins based on hemoglobin profile and morphometry. Pp. 129-139 in The bottlenose dolphin (Leatherwood, S., and R. R. Reeves, eds.). Academic Press. San Diego, USA.

Hershkovitz, P. 1966. Catalog of living whales. Bulletin of the United States National Museum 246:1-259.

Hoelzel, R., C. W. Potter, And P. B. Best. 1998. Genetic differentiation between parapatric "nearshore" and "offshore" populations of the bottlenose dolphin. Proceedings of the Royal Society of London B 265:1177-1183.

Juárez Rodríguez, M. 2008. Variación morfológica de la aleta dorsal de la tonina (Tursiops truncatus, Montagu 1821) en la Bahía de Banderas, México. Tesis de licenciatura. Escuela de Biología, Benemérita Universidad Autónoma de Puebla. Puebla, México.

Kingston, S. E., And P. E. Rosel. 2004. Genetic differentiation among recently diverged delphinid taxa determined using AFLP markers. Journal of Heredity 95:1-10.

Lowther-Thieleking, J. L., F. I. Archer, A. R. Lang, and D. W. Weller. 2015. Genetic differentiation among coastal and offshore common bottlenose dolphins, Tursiops truncatus, in the eastern North Pacific Ocean. Marine Mammal Science 31:1-20.

Medrano González, L. 2006. Hacia una dinámica de la mastofauna marina mexicana: Análisis de composición funcional y de algunas estructuras genéticas poblacionales. In Genética y mamíferos mexicanos: Presente y futuro (Vázquez-Domínguez, E., and D. J. Hafner, eds.). New Mexico Museum of Natural History and Science Bulletin 32:9-19.

Medrano González L., E. Peters Recagno, M. J. Vázquez Cuevas, and H. Rosales Nanduca. 2007. Los mamíferos marinos ante el cambio ambiental en el Pacífico tropical mexicano. Biodiversitas 75: 8-11.

MejíA-Olguín, A. 2004. Estructura social de Tursiops truncatus Montagu, 1821 (Cetacea: Delphinidae) en la Bahía de Banderas, México. Tesis de licenciatura. Facultad de Ciencias, Universidad Nacional Autónoma de México. Ciudad de México, México.

Morteo Ortiz, E. 2004. Dorsal fin morphological differentiation in bottlenose dolphins (Tursiops truncatus) along Mexican coasts: an adaptive approach. Tesis de maestría. Centro de Investigación Científica y de Educación Superior de Ensenada. Ensenada, México.

Natoli, A., V. M. Peddemors, and A. R. Hoelzel. 2004. Population structure and speciation in the genus Tursiops based on microsatellite and mitochondrial DNA analyses. Journal of Evolutionary Biology 17:363-375.

Perrin, W. F. 1984. Patterns of geographical variations in small cetaceans. Acta Zoológica Fennica 172:137140. 
Perrin, W. F., J. L. Thieleking, W. A. Walker, F. I. Archer, and K. M. Robertson. 2011. Common bottlenose dolphins (Tursiops truncatus) in California waters: Cranial differentiation of coastal and offshore ecotypes. Marine Mammal Science 27:769-792.

Pompa-Mansilla, S. 2007. Distribución y abundancia de los géneros Steno y Kogia en Bahía de Banderas y aguas adyacentes. Tesis de maestría. Posgrado en Ciencias Biológicas, Universidad Nacional Autónoma de México. Ciudad de México, México.

RICE, D. W. 1998. Marine mammals of the world. Systematics and distribution. Special publication 4, The Society for Marine Mammalogy. Lawrence, USA.

Rodríguez Vázquez, M. E., E. Lugo Cabrera, and Z.C. Foubert Corona. 2003. Ecología, comportamiento y estructura social de un grupo residente de tursiones (Tursiops truncatus) en Bahía de Banderas. Abstract 7 in XXVIII Reunión internacional para el estudio de los mamíferos marinos. Nuevo Vallarta, México.

Rosel, P. E., A. E. Dizon, And J. E. Heyning. 1994. Genetic analysis of sympatric morphotypes of common dolphins (genus Delphinus). Marine Biology 119:159-167.

Ruiz Boijseauneau, I. 1995. Distribución y abundancia de Tursiops truncatus Montagu, 1821(Cetacea: Delphinidae) en la Bahía de Banderas y aguas adyacentes, México. Tesis de licenciatura. Facultad de Ciencias, Universidad Nacional Autónoma de México. Ciudad de México, México

Salinas Zacarías, M. A., and L. F. Bourillón Moreno. 1988. Taxonomía, diversidad y distribución de los cetáceos de la Bahía de Banderas, México. Tesis de licenciatura. Facultad de Ciencias, Universidad Nacional Autónoma de México. Ciudad de México, México.

SchnelL, G. D., M. E. Douglas, And D. J. Hough. 1986. Geographic patterns of variation in offshore spotted dolphins (Stenella attenuata) of the eastern tropical Pacific Ocean. Marine Mammal Science 2:186213.

Segura, I., A. Rocha-Olivares, S. Flores-Ramírez and L. Rojas Bracho. 2006. Conservation implications of the genetic and ecological distinction of Tursiops truncatus ecotypes in the Gulf of California. Biological Conservation 133:336-346.

Urbán Ramírez, J. 1983. Taxonomía y distribución de los géneros Tursiops, Delphinus y Stenella, en las aguas adyacentes a Sinaloa y Nayarit, México (Cetacea, Delphinidae). Tesis de licenciatura. Facultad de Ciencias, Universidad Nacional Autónoma de México. Ciudad de México, México.

Vidal Hernández, L. E. 1993. Variación geográfica de las dimensiones craneanas en toninas (Tursiops truncatus) del Mar de Cortés, México. Tesis de licenciatura. Facultad de Ciencias, Universidad Nacional Autónoma de México. Ciudad de México, México.

Viloria Gómora, L. 2007. Identidad, distribución espacio-temporal y abundancia de Tursiops truncatus en Bahía de Banderas, México. Tesis de maestría. Posgrado en Ciencias del Mar y Limnología, Universidad Nacional Autónoma de México. Ciudad de México, México.

WALKER, A. W. 1981. Geographical variation in morphology and biology of bottlenose dolphins (Tursiops) in the eastern North Pacific. Administrative report LJ-81-03C. Southwest Fisheries Science Center, National Marine Fisheries Service. La Jolla, USA.

WANG, J. Y., L.-S. Chou, AND B. N. White. 1999. Mitochondrial DNA analysis of sympatric morphotypes of bottlenose dolphins (Genus: Tursiops) in Chinese waters. Molecular Ecology 8:1603-1612.

Wang, J. Y., L.-S. Chou, ANd B. N. White. 2000. Differences in the external morphology of two sympatric species of bottlenose dolphins (Genus Tursiops) in the waters of China. Journal of Mammalogy 81:1157-1165.

WRIGHT, S. 1932. The roles of mutation, inbreeding, crossbreeding and selection in evolution. Pp. 356366 in Proceedings of the Sixth International Congress of Genetics, Vol. 1 (Jones, D. F., ed.). Genetics Society of America. Austin, USA. 
Summited: February 25, 2015

Review: March 12, 2015

Accepted: May 20, 2015

Associated editor: Juan Pablo Gallo 
TURSIOPS TRUNCATUS MORPHOTYPES 